carefully sought, and treated hy diet, phosphorus, and lime, you will not have done your whole duty. Most painstaking and thorough should he your investigation of the digestive system and correction of all its errors. Judicions warnings should he given to parents of precocious children, urging them to forhear the exhihition of the unnatural hrightness of the tender little minds, and to protect them from traumatism, as these children seem to he prone to fall, hecause, as I helieve, they are slow to acquire spatial and postural judgment.

\title{
Bibloorapiy.
}

Romberg and Henoch. Kllnische Wahreaehmungen v. Beobachlungen, 8. 57. Berlin, 1851. Elenoch. Iectnres on niseases of Children.

Faber. Referred to hy Henoch.

Ebert. Referred to hy Henoch.

Hnghling Jackion. Iancet, October $26,1899$.

Buzerird. Lancet, 1850, vol. L. p. 83t.

Demme Referred to by Finden.

Gortion Norte, of Copenhagen. Centralbl. C. prakt. Angenheilk., Atigost, Beptcmber, 18s8, p. 2-20, See The Oph thalmic Ilerlew, IRSs, p. 355 .

B. Gee, St Bartholomew'i Hospltal Reports, rol, xxll. p. 26 .

W. A. Fadden. Iancet, June 14, 21, 28, 1890. Bt. Thomes' Faspital Reports, 1890.

Peterson. Medical tieks, rol, 1nt. p. 374.

Welr Mitchell. Hedical News, Mareb \&, 1893.

Stephen Mrkenzle, Lapceh 1886, rol. L. p. 137.

Gowen Dlsenses of the Hervous Brter.

C. F. Mrtlts. American Textbook of Discases of Chlldren, p. 712

Osler. On Chorea, p. 89 .

Suchs. Nerrous Dlsesses of Cblldrea, p. 197.

A. Baglasky. Referred to by Mrllis.

IAzinaky. Medlcal News, AprI $28,1898$.

Jacoht Hedical News, A prll 23, 1898.

Hersch. Aredical kiew, Aprit 23,1895 .

\section{EXTERNAL URETHROTOMY.'}

\author{
BY Jahes R. HAYDEN, M.D., \\ NEW YORE.
}

Extensal, urethrotomy for the relief of stricture is an operation so frequently performed hy the memhers of this Association that it is with some hesitation I hring it hefore them for their consideration and discussion.

My ohject in so doing is not to ndrance new or original methods, hut rather to accentuate certain points in the technique of the operation nnd the after-treatment of the case, which in my hands have given hetter and more permanent results than are frequently encountered following this operative procedure. Such conditions as recontraction of the \footnotetext{
1898.

1 Read before the American Assoclstion of Genllo-Urinary Surgeons, West Polnt, June 7,
98 .
} 
stricture, perineal ahscess, or fistala, and uncured urethro-cystitis are not uncommoa, heing due partially to the patient's ignoraace or neglect, nnd partinlly to faulty operative and post-operative procedures, and can in a great measure be aroided if the following points are carefully carried out.

Drvision of tas Stricture. The patient having heen properly prepured and plnced, the urethra is opened on its floor hy $\mathrm{n}$ single clean incision and all of the stricture tissue completely divided in the median line, not only oa the floor, hut nlso on the roof of the canal; this Iatter procedure I am convineed is not invnriahly carried out, as in many of these cases which $I$ have persoaally examined, on endeavoring to pass a sound some time nfter the operation (in one case as early as the second week, ia two crses nt the end of the fourth week, and others nt loager intervnls) a mass of iadurated tissue could be distinctly felt projecting from the roof of the canal, to pass over nad, if possihle, heyond which, the tip of the instrumeat had to he forcihly depressed toward the perineum ; this mass I take to he unent strictnre-tissue, or if it was divided nt the time of the operation, this was not completely done, or was not followed hy proper local measures. It is claimed by some that cutting on the roof of the caasl ia this region is liahle to cause serere hemorrhage; this accideat, if it occurs, is due, I think, to over-zealous cutting, with a. view to subsequently passing unnecessarily large sounds. In over eighty of these cases I have not had any hemorrhage eitler at or nfter the operation. In order to ascertain if nll of the stricture tissue has heen completely divided the iadex-fiager, with the palmar surface directed upward, should be passed into the periaenl wound and down to healthy urethra, well in froat of the stricture, nnd then hnck ward on the roof of the canal into the hladder, as on its wny it readily detects any hands or masses that have not heen thoroughly divided; whereas, if a souad passed from the meatus be alone relied on, it will usually eater the bladder with ease, as the floor of the urethra, heing cut away, allows the coavexity of the instrument to hulge down and out aad the tip to slip over the ohstruction on the roof, thus giving the operator a fnulty idea as to the real coadition of the canal. The dilatation of the posterior urethra hy the index-fioger prased ia to the hladder, prevents ia n great measure post-operative teaesmus, as in the majority of these cases this portion of the canal is found to he so rigid, firm, and contracted that it often requires several minntes to overcome this condition and restore its normal patulousness; in other words, we over-dilate and paralyze the coatracted prostatic fihres, nnd in this way prevent their physiological action for some time, thus giving the gland and hladder much-needed rest and reducing their inflamed and coagested condition. The periaeal operation heing completed, $n$ full-sized sound should he passed from the meatus into the hladder, to ascertain that the whole 
length of the urethra is clear; if ohstructions exist, they may he removed hy meatotomy, internal urethrotomy, or post-operative dilatation.

Bladder Drainage. Blndder drainage after these operations is a most important factor, and seems, judging from the liternture and the work of different operators, to he as yet an unsettled question, hoth as regards the hest method of, and proper time for, the retention of the drain, some advising the use of a silver or soft-rubber cutheter, draining through the urethra; others ganze drainage through the wound; some no drainage at all, and still others a large perineal tuhe, which Intter method is in nyy experience far the hest, if properly employed, as it keeps the hladder well drained, dilntes the posterior urethra and, to a certain extent, the divided stricture, nnd is an ever-rendy route for hladder irrigations, which nre so essential in the treatment of the urethro-cystitis which so often exists in these cases, and which, strange to say, is so frequently iguored or overlooked. A large soft-ruhber perineal tuhe is selected and introduced into the hladder just fur enough to nllow the urine to drain freely. This position is accurately ascertained at the time of the operation hy irrigating the bladder through the tuhe and noting the nmount nad force of the outflow as the tube is slowly withdrawn. The tube is then secured in place hy a heavy silk suture passed directly through it and hoth edges of the wound, which is then lightly packed with gauze, and the suture tied, thus preventing the tuhe from slipping cither in or out; the hladder is then irrigated and partially filled with warm boric acid or salt solution nnd the tuhe clamped until the patient is put to hed, when it is attached to the usual siphon apparatus. The receptacle for the urine should he placed somewhat lower than the hladder, hut not too low, as the suction then hecomes quite strong nnd causes some patients pecinful sensations in the hladder, with, perhaps, tenesmus.

In from two to four days after the operation the tube is taken out, washed, and replaced; it is removed permanently on the fifth to the seventh day, and the patient is nllowed to be up nnd nhout nnd passing his urine hoth by the urethra and the perineal incision, pressing a pad of gauze against the wound as he does 80 . In the majority of cases all of the urine is passed hy the urethra in about one week after the removal of the tuhe, hut in some the urethral wound remains patulous for several weeks. This usually occurs in cases in which the perineal wound has not received proper trestment, and when no sounds have heen passed either at or after the operation; also in alcoholic or dehilitated subjects, and in cases in which the urethra has heen extensively cut for the cure of urinary fistule and sinuses.

Post-operatrve Dilatation. When the tuhe is first taken out, on the second or the fourth day, for cleaning, a mediun-sized sound is passed to the hladder and held there for nhout a minute; this is repented 
regularly every second or third day, natil the perineal wound is cicatrized, and the urethra taking a No. 28 to 30 French with ease, according to ths case, when the intervals are made longer. It is surprising to note how littls pain the passage of the first souad causes, provided it he warm, well luhrieated, and introduced slowly, with its tip hugging ths roof of the canal. After the sound is removed the tuhe is replaced nnd the hladder and urethra nre gently irrigated with hot horic acid or sslt solution, and on the alternnte days, if iadicated, with mild solutions of permanganate of potassium or nitrate of silver.

Treatarest of the Perineal Wound. The perineal wound should bs personally inspected every day to see thnt it is healing solidly from the hottom hy firm, healthy granulations, and not allowed to bridge over in places or fill up with pale, flahhy tissue. This can he prevented hy running the finger firmly, hut geutly, through the hottom of the wound from end to end, the pntient lyiug on his ahdomen, or in tho lithotomy position, with thighs widely separated, and in a good light; exuherant granulations are removed hy the nitrate of silver stick or curved scissors, aud the wound dressed lightly with gauze. When the periaenl wound is cicatrized, the urethrn taking $\mathbf{n}$ full-sized sound with ease and the urethro-cystitis improving, the patient must he made to underatund clearly that the operation has not cured his stricture, hut merely divided it, and that he must continue to have sounds parsed . at long intervals for the remainder of his life; also that he must not stop bladder or urethmal medication until urination is normal and the urine practically free from tissue elemente.

The following cases, hriefly detailed, have been selected from my records, as they show results dating from two years to two years and a holf after operation, and may therefore be considered of value. Mrany similar cases could have heen given, but these were deemed sufficient to illustrate the ahove points. In one case the stricture wns traumatic, in the others gonorrhael in origin, one patient having three wellmarked contractions. The operations performed included those of Gouley, Wheelhouse, and a comhined internal and external urethrotomy.

Case I.-Patient aged forty years. One gonorrhoenl stricture at hulho-memhranous junction, impassable to instruments. Severe urethrocystitis. Wheelhouse operation. Fourth dny: Perineal tuhe taken out, cleaned, and replaced, and a No. 25 French sound passed. Fiftl day: Tuhe removed permanently. Seventh day: All urine passed by ths urethra. Patient up and ahont. Fourteenth day: Wound cientrized. Examination of this patient two and one-half years nfter the operation shows the urine to hs clear, with a few light, flonting mucous flnkes, the urethra soft and taking a Nn. 28 French sound with ease. Urinntion is normal.

CASE II.-Patjent nged thirty-twn years. One gonorrhœul stricture in the hulhous urethra, admitting a filiform. Severe urethro-cystitis. 
Gouley's operation. Fifth day: Tube takea out permanently, aad a No. 25 French sound passed. Patieat up and about. Ninth day: All urine passed hy the urethra. Fourteenth day: Wound cicatrized. Two and oae-half ycars after operation this patieat takes a No. 30 Freach sound with ease, urination is normal, and the urine practically
clear.

CASE IIL-Patient aged forty-five years. Oae traumatic stricture, admitting a filiform, at hulho-membranous juactioa. Ammoaiacal cystitis. Gouley's operation. Second day: Tube taken out, washed and replaced, and a No. 28 Freach sound passed. Fifth day: Tuhe removed permaneatly. Patient up. Teath day: All uriae passed hy urethra. Sixteenth day: Wound cicatrized. Two years after the operation this patient takes a No. 30 Freach souad with ease, urinates normally, and his uriae is clear, with a few ligbt flakes.

CASE IV.-Patieat aged tweaty-three years. Three dease goaorrhoeal strictures; two iu peadulous urethra, admitting Nos. 15 nad 17 French, respectively, and oae in hulbous urethra, takiug a filiform. Very severe urethro-cystitis. Internal and external urethrotomy. Third day: Tube taken out, washed, and replaced, and a No. 27 Frencb sound pased. Fiftb dny: Tuhe removed permaneatly. Seventb day: All urioe passed hy urethra. Patient up and about. Fifteeath day: Wound cicatrized. Two years after operation patient takes a No. 30 Frencb sound witb ease, his uriae is clear, and urinntion normnl.

\title{
A REPORT ON BIX CASES IN WHICH THE BACILLUS A B̉ROGENES CAPSULATUS WAS ISOLATED.
}

\author{
By Cearles Norry, Ph.B., Mi.D., \\ or NEW YORE.
}

The occurreace of gas ia the living tissues aad tbe presence of gas after death in larger and smaller hubbles in the viscera, especially in the liver, has loag been known, and the cause and significance variously iaterpreted hy clinicians and pathologists. The appearaace of the viscern when riddled with gas-buhbles is so striking and 'peculiar that tbey are descrihed by the Germans as " schaumorgane," foam-organs. In some instances air emholism was held accouatahle for the condition, especially whea occurriag after surgical operations or after ebildbirth. It was suspected hy others that anaermbic hacilli, wanderiag out of the iatestiaal caanl after denth, give rise to the gas productions. It was thus held to be a form of post-mortem decomposition, and little atten. tion was directed to it uatil the appearance of an article by Welch and Nuttall ia 1892.

With the aaaērohic bacillus, which they isolated in pure culture from the organs of their case and which they described and aamed the bacillus aẽrogeaes capsulatus, they were nble to reproduce in the tissues of dead 
rahhits, after distrihution of the hacilli througb the circulation intra vitam, a complete picture of the so-called "schanmorgane" of the Germais. The causal relation hetween this condition snd the hacillus was thus thoroughly estahlished. Animal experimeatatioa further coaviaced them that to produce such a geaeral and exteasive emphysema of the organs aad tissues as was present in their case it was aecessary to inject the hacilli during the continuance of the circulatioa, injection ia to the hloodressels after denth beiag followed oaly by an emphysema along the direct course of the vessels inoculated. This noteworthy fact, and the appearance of necrosis and degeaeration in the tissues arouad the masses of hacilli and gas-cysts in the orgaas of their case, led then to suppose that a terminal iafection with the hacillus had taken place. Except in its application to a very limited class of cases, the old views coacerniag the air-emholism were thus destroyed at oae stroke. Too great credit cannot he attached to the authors of this article, $2 s$ it has removed a piece of medisvalism coaceraing air-emholism from the minds of the medical professioa.

To Eug. Frneakel ${ }^{2}$ heloags the credit of bringiag out the cansal relation between the bacillus phlegmones emphysematozac and gaseous phlegmoas. This hacillus is considered hy Welcb as identical with his hacillus aërogeaes capsulatus. To the classical description of ths morphology and cultural chancteristies of the hacillus little of importance has siace heen added, except the discovery of the formation of spores on blood-serum hy Dunham."

Since the publication of Welch and Nuttall's preliminary study, and the study of Fraeakel oa the hacillus aërogenes capsulatus, many instances of its occurrence have heen described. A partial summary of the cases puhlished previous to the year 1896, with furtber studies oa tbe hacillus aërogeaes capsulatus, is to he fouad in a second paper, not yet completed, hy. Welch and Flexaer,' puhlished in the Journal of Experimental Mfedicine, 1896. The association of a well-defined hacterium with the ante-mortem or post-mortem development of gas in the hody is now well estahlished, and a large number of illustrative cases is at our disposal, so that the record of new iastaaces of the isolation of the hacilli aërogeaes capsulatus would be itself of hut moderate value. However, the coaditions under which iafection with the germ occurs, its full signiticance either as a primary or concurrent infection, and the relative frequency with which its preseace is simply a post-mortem incident, offer such a series of uasolved prohlems as makes still desirahle an iacreased number of examiantions and records of experiments.

The iatention of this paper is to give hriefly the more important clinical dats ohtaiaahle ia the histories of six new cases examiaed hy the writer, with the hacteriological anslyses, microscopical lesions, etc. At the ead of the description of each case a hrief summary of the cases in 